\title{
Three new species of Stigmatodiscus from Mallorca (Spain)
}

\author{
Hermann Voglmayr ${ }^{1}$ (D) Angel Pintos Amengual ${ }^{2}$ \\ Received: 23 July 2018 / Revised: 17 August 2018 / Accepted: 22 August 2018 /Published online: 10 September 2018 \\ (C) The Author(s) 2018
}

\begin{abstract}
During a survey on corticolous Dothideomycetes in Mallorca, several collections with ascomata, asci, and ascospores matching the genus Stigmatodiscus (Stigmatodiscales, Dothideomycetes) were revealed, which did not fit any described species. Therefore, these collections were cultured and sequenced, and a multigene matrix of four loci (nuc18S-ITS-28S rDNA, $r p b 2$, tefl and tub2) was produced. Based on the results of the phylogenetic analyses of this matrix and of morphological investigations, three new species (Stigmatodiscus labiatus, S. oculatus, and S. pinicola) are described and illustrated, Asterodiscus is synonymised with Stigmatodiscus and the new combination S. tamaricis is proposed. A key to all currently known species of Stigmatodiscus is provided.
\end{abstract}

Keywords Ascomycota $\cdot$ Dothideomycetes $\cdot$ Multigene phylogenetic analysis $\cdot$ Stigmatodiscaceae $\cdot$ Taxonomy $\cdot 3$ new species $\cdot 1$ new combination

\section{Introduction}

During a study of corticolous ascomycetes of Mallorca, the second author made several collections of dothideomycetes with hysteriform to apothecial ascomata embedded in host tissue and lacking an excipulum, which showed a character combination of branched, septate, apically swollen paraphyses with dark brown incrustation, saccate, bitunicate asci, and large, brown, asymmetric, one- or three-septate ascospores with an excentric euseptum and eventually two additional distosepta with large pores, each hemispore part being surrounded by a gelatinous sheath. These characters resembled the recently described genus Stigmatodiscus (Voglmayr et al. 2016, 2017), but the Mallorcan collections did not match any described species. Therefore, they were isolated it in pure culture; DNA sequence data of nuc18S-ITS-28S rDNA, $r p b 2$, $t e f 1$, and $t u b 2$ were generated for phylogenetic analyses; and

Section Editor: Marc Stadler

Hermann Voglmayr

hermann.voglmayr@univie.ac.at

1 Division of Systematic and Evolutionary Botany, Department of Botany and Biodiversity Research, University of Vienna, Rennweg 14, 1030 Vienna, Austria

2 Departamento de Investigación Micologica, Cultivos Pima S.L., Calle Son Pereto no 50 Bj, 07013 Palma de Mallorca, Spain detailed morphological examinations were conducted. As a result, three new species of Stigmatodiscus were revealed, which are here described and illustrated.

\section{Materials and methods}

\section{Morphological observations}

Stereomicroscopy illustrations were captured either with a Keyence VHX-6000 system or with a Nikon SMZ 1500 stereomicroscope equipped with a Nikon DS-U2 digital camera. For certain images of ascomata, the stacking software Zerene Stacker version 1.04 (Zerene Systems LLC, Richland, WA, USA) was used. Hand sections of ascomata and conidiomata were made using a razor blade and mounted in water or $3 \%$ $\mathrm{KOH}$ on a microscope slide, gently torn apart with a preparation needle when necessary and covered with a cover slip. Slides were examined and photographed using a Zeiss Axio Imager.A1 (Zeiss, Jena, Germany) microscope equipped with a Zeiss Axiocam 506 colour digital camera. Measurements were done with the Keyence VHX-6000, NIS-Elements D v.3.0 or Zeiss ZEN Blue Edition software packages and are reported as maxima and minima in parentheses and the range representing the mean plus and minus the standard deviation of a number of measurements given in parentheses. The specimens were deposited in the fungarium of the University of Vienna (WU). 


\section{Pure culture isolation}

Mature ascomata on corticated twigs were horizontally cut using a sterile razor blade, the apothecia separated from the surrounding host tissue, transferred to a sterile drop of water on a microscope slide, torn apart with a forceps to release the ascospores from asci, which were pipetted on a $2 \%$ malt extract agar (MEA) plate supplemented with $200 \mathrm{mg} / \mathrm{l}$ penicillin $\mathrm{G}$ and streptomycin sulphate (Sigma-Aldrich, St. Louis, MO). Germinated ascospores were then transferred to 2\% MEA or $2 \%$ corn meal agar (CMA, Sigma-Aldrich) supplemented with $2 \% \mathrm{w} / v$ dextrose (CMD) plates, which were sealed with laboratory film and incubated at 16 or $22{ }^{\circ} \mathrm{C}$. Cultures were deposited at the Westerdijk Fungal Biodiversity Centre, Utrecht, The Netherlands (CBS culture collection).

\section{DNA extraction, PCR and sequencing}

Growth of liquid cultures and extraction of genomic DNA was done according to Voglmayr and Jaklitsch (2011), using the DNeasy Plant Mini Kit (QIAgen GmbH, Hilden, Germany). The following sequence regions were used for identification and phylogenetic analyses: the complete nucITS region and D1 and D2 domains of nuc28S rDNA region (ITS-LSU) were amplified using the primers V9G (de Hoog and Gerrits van den Ende 1998) and LR5 (Vilgalys and Hester 1990). The nuc18S rDNA region (SSU) was amplified with primers SL1 (Landvik et al. 1997) and NS24mod (Voglmayr and Jaklitsch 2011). A ca $1.2 \mathrm{~kb}$ fragment of the RNA polymerase II subunit 2 ( $r p b 2)$ gene was amplified using the primers fRPB2-5f and fRPB2-7cr (Liu et al. 1999). A ca 1.3-1.7 kb fragment of translation elongation factor $1-\alpha(t e f 1)$ gene was amplified with the primers EF1-728F (Carbone and Kohn 1999) and TEF1-LLErev (Jaklitsch et al. 2005) or EF12218R (Rehner and Buckley 2005), and a ca $0.8 \mathrm{~kb}$ fragment of the beta tubulin (tub2) gene with primers T1 (O'Donnell and Cigelnik 1997) or T1HV and BtHV2r (Voglmayr et al. 2016). PCR products were purified using an enzymatic PCR cleanup (Werle et al. 1994) as described in Voglmayr and Jaklitsch (2008). DNA was cycle-sequenced using the ABI PRISM Big Dye Terminator Cycle Sequencing Ready Reaction Kit v. 3.1 (Applied Biosystems, Warrington) and the PCR primers; in addition, the following primers were used: ITS-LSU region: ITS4 (White et al. 1990), LR2R-A (Voglmayr et al. 2012) and LR3 (Vilgalys and Hester 1990); SSU: NS1088 (Kauff and Lutzoni 2002). Sequencing was performed on an automated DNA sequencer (ABI 3730x1 Genetic Analyzer, Applied Biosystems).

\section{Phylogenetic analyses}

To reveal the phylogenetic position of the new isolates produced in the present study, a matrix of aligned nucleotide sequences from the four different phylogenetic markers (SSU-ITS-LSU, rpb2, tef1 and tub2) was produced. GenBank sequences of four taxa (Anisomeridium ubianum and Megalotremis verrucosa from Monoblastiales, Dyfrolomyces rhizophorae from Dyfrolomycetales and Palawania thailandense from Palawaniaceae) were selected as outgroup according to Voglmayr et al. (2017) and the results of BLAST searches. Sequences were aligned with the server version of MAFFT (www.ebi.ac.uk/Tools/mafft) and subsequently checked and refined using BioEdit version v. 7.0.9.0 (Hall 1999). For alignment of rpb2, the alignment was translated into a protein matrix and the gap positions corrected according to the codons. The combined sequence matrix contained 6723 nucleotide positions (1770 from SSU, 1514 from ITS-LSU, 1167 from rpb2, 1417 from tef1, 855 from tub2). GenBank accession numbers of the sequences included in the phylogenetic analyses are given in Table 1.

Maximum likelihood (ML) analyses were performed with RAxML (Stamatakis 2006) as implemented in raxmlGUI 1.3 (Silvestro and Michalak 2012), using the ML + rapid bootstrap setting and the GTRGAMMA substitution model with 1000 bootstrap replicates. The matrix was partitioned for the individual gene regions, and substitution model parameters were calculated separately for them.

Maximum parsimony (MP) analyses were performed with PAUP v. 4.0a161 (Swofford 2002), using 1000 replicates of heuristic search with random addition of sequences and subsequent TBR branch swapping (MULTREES option in effect, steepest descent option not in effect). All molecular characters were unordered and given equal weight; analyses were performed with gaps treated as missing data; the COLLAPSE command was set to NO. Bootstrap analysis with 1000 replicates was performed in the same way, but using 5 rounds of random sequence addition and subsequent TBR branch swapping during each bootstrap replicate.

Bootstrap support below $70 \%$ was considered low, between 70 and $90 \%$ medium/moderate and above $90 \%$ high.

\section{Results}

\section{Molecular phylogeny}

For S. pinicola, no tef1 could be obtained. Of the 6723 nucleotide positions, 1016 were parsimony informative (64 from SSU, 310 from ITS-LSU, 258 from $r p b 2,231$ from tef1 and 153 from $t u b 2$ ). The parsimony analyses revealed $27 \mathrm{MP}$ trees 2398 steps long, one of which is shown as phylogram in Fig. 1. Tree backbone of the 27 MP trees was identical, except for minor differences within $S$. enigmaticus. The best tree revealed by RAxML $(-\ln =20,909.518)$ was fully compatible with the MP strict consensus tree. 


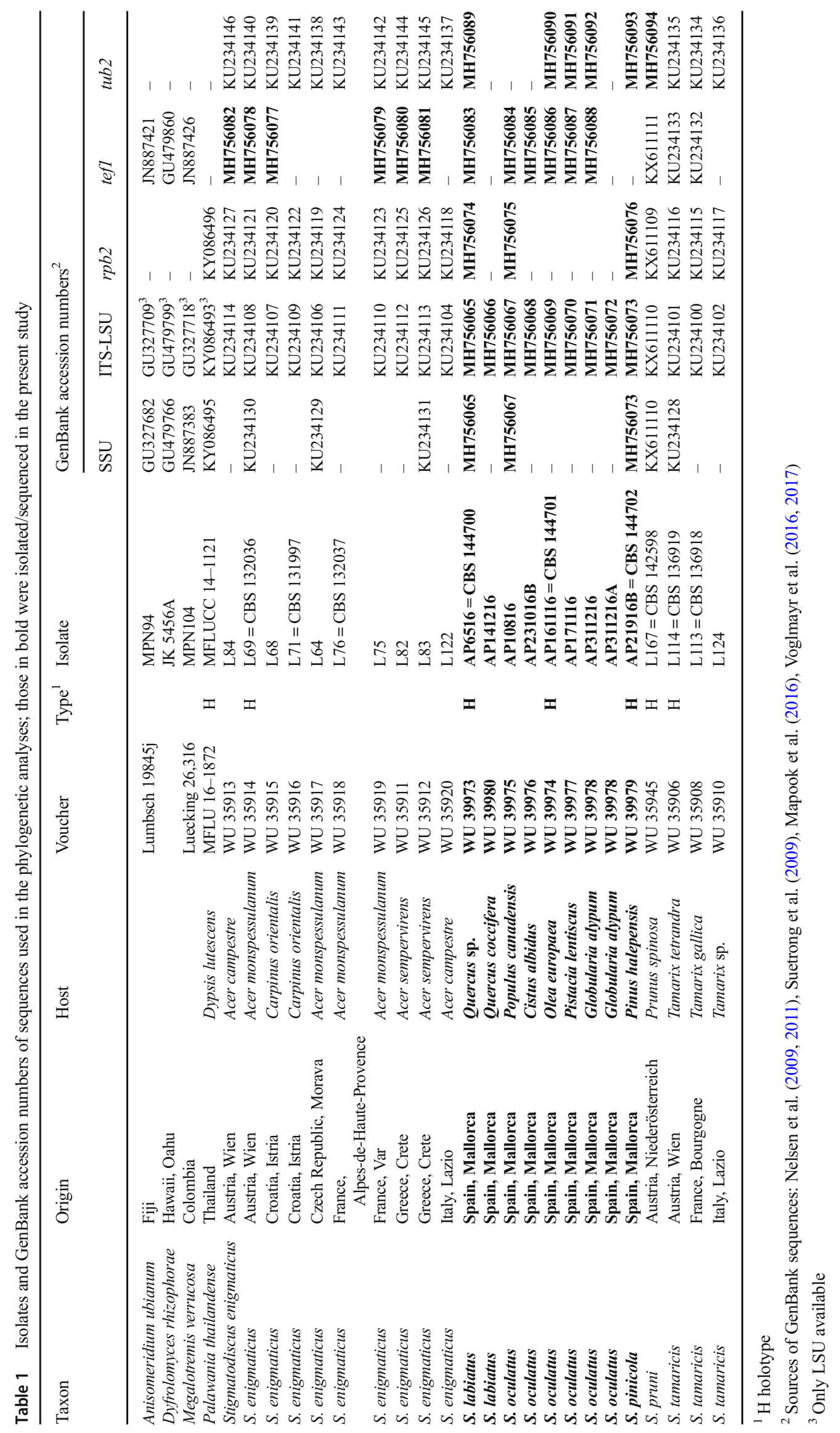


Fig. 1 Phylogram showing one of 27 MP trees 2398 steps long obtained from an MP analysis of the combined multigene matrix of nucSSU-ITS-LSU rDNA, $r p b 2$, tef1 and $t u b 2$ from Stigmatodiscus. MP and ML bootstrap values above $50 \%$ are given at first and second position, respectively, above the branches. The isolates of the new species described in the present study are formatted in bold

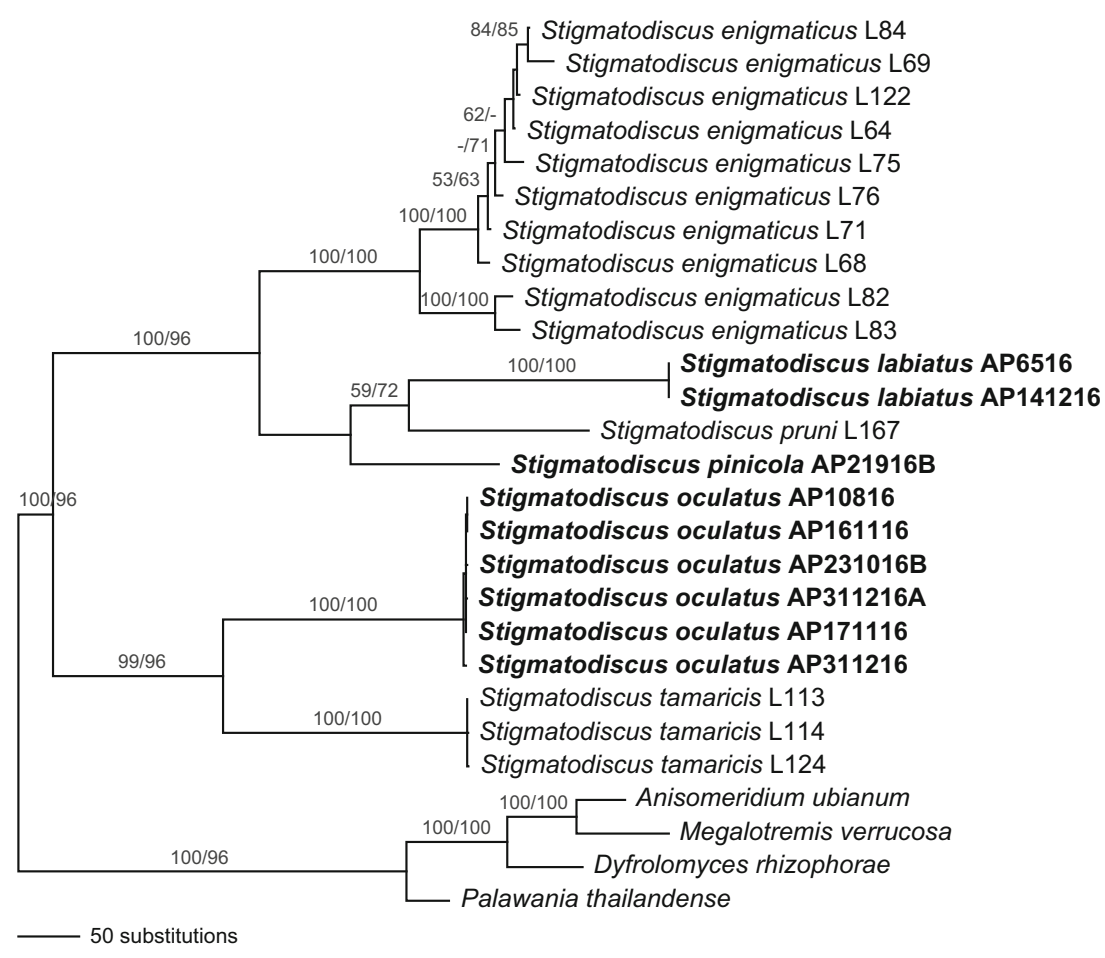

In the MP and ML analyses, the Stigmatodiscales were highly supported, and all Stigmatodiscus species for which more than one accession was sequenced received maximum support. Within Stigmatodiscus, the newly described Stigmatodiscus oculatus formed a highly supported clade with Asterodiscus tamaricis, and this clade was revealed as sister group to the other Stigmatodiscus species with high support. The newly described S. labiatus clustered with $S$. pruni with low (59\% MP) to medium (72\% ML) support, and the newly described $S$. pinicola was placed as sister species to the S. pruni-S. labiatus clade without support. The clade containing S. enigmaticus, S. labiatus, S. pinicola and S. pruni received maximum (MP) or high (96\% ML) support, but within this clade, the sister group relationship of $S$. enigmaticus to the S. pinicola-S. pruni-S. labiatus subclade was unsupported.

\section{Culture characteristics}

Culture images of the three new Stigmatodiscus species grown on CMD are shown in Fig. 2. Detailed culture descriptions are given under the respective species.

\section{Taxonomy}

Stigmatodiscus labiatus Voglmayr \& Pintos, sp. nov. Figs. 3, 4. MycoBank MB 827487.

Etymology: Referring to the lip-shaped ascomata.

Ascomata hysteriform, scattered, rarely gregarious or confluent, corticolous, erumpent through the periderm, in face view (275-)380-1000(-1610) $\mu \mathrm{m}$ long, (145-)200-350(-
570) $\mu \mathrm{m}$ wide $(n=51)$, with sides consisting of usually two, rarely three black lips (peridium), (45-)90-170(-200) $\mu \mathrm{m}$ wide $(n=50)$, with a narrow central slit, usually closed when dry and not exposing the blackish elongated disc. Bark tissues not visibly altered, no black line visible in bark or wood. Peridium coriaceous, pseudoparenchymatous, black, up to $130 \mu \mathrm{m}$ thick at the apex, $17-31 \mu \mathrm{m}$ thick at the sides, almost absent to $10 \mu \mathrm{m}$ thick at the base, composed of small angular to rounded, dark brown, thick-walled cells 4-8 $\mu \mathrm{m}$ diam. Hamathecium composed of hyaline, septate, filiform branched paraphyses $1.7-3 \mu \mathrm{m}$ wide, embedded in a tough hymenial gel, simple, not anastomosing, 82-130 $\mu \mathrm{m}$ long, longer than asci, swollen at their apices up to $4 \mu \mathrm{m}$ and incrusted with dark brown granules forming an epithecium, neither staining blue in Lugol nor in Melzer's reagent after pre-treatment with $3 \% \mathrm{KOH}$. Asci (67-)78-103($108) \times(41-) 43-59(-71) \mu \mathrm{m}(n=18)$, bitunicate, broadly ellipsoid to globose, almost sessile, with a distinct apical chamber, thick-walled, typically containing 8 irregularly bi- to triseriate ascospores, very stable, fissitunicate dehiscence not observed. Ascospores (34.5-)38-43(-47.5) × (13.8-)15.5$17.5(-19.3) \mu \mathrm{m}, 1 / \mathrm{w}=(2.2-) 2.3-2.6(-2.8)(n=84)$, brown, asymmetric, broadly fusiform, straight, 1-septate, strongly constricted at the septum, each hemispore surrounded by a separate gelatinous sheath quickly dissolving in water, upper cell slightly broader, with broadly rounded ends and distinctly constricted in the middle with a ring-like thickening inside; wall finely verruculose, brown, the contents granular, usually with a large and several smaller guttules per cell. 
Fig. 2 Stigmatodiscus cultures on CMD after 42 days at $16^{\circ} \mathrm{C}$; a-c in face view, $\mathbf{d}-\mathbf{f}$ reverse. $\mathbf{a}, \mathbf{d}$ S. labiatus; $\mathbf{b}, \mathbf{e} S$. oculatus; $\mathbf{c}, \mathbf{f}$ S. pinicola. Sources: a, d AP6516; b AP231016; c, f AP21916b; e AP311216

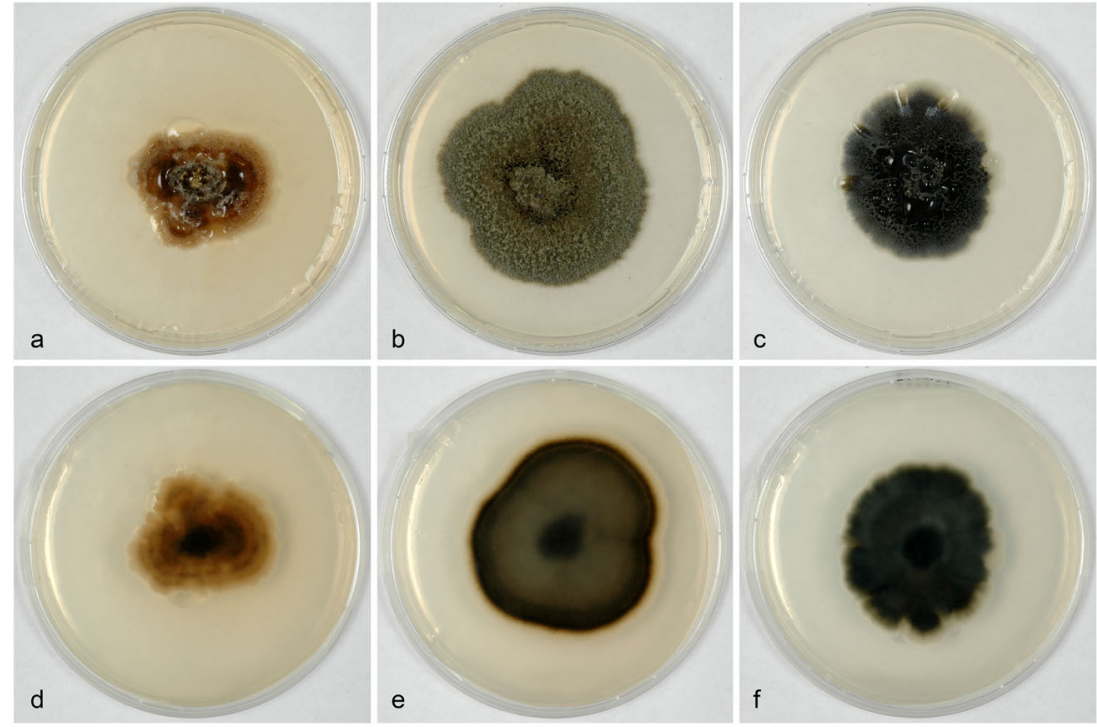

Conidiomata on the natural substrate associated with ascomata, visible as minute black dots $80-160 \mu \mathrm{m}$ in diam, immersed, peridermal, pycnidial, unilocular, of circular shape, opening with a central ostiole, 100-200 $\mu \mathrm{m}$ diam, marginal wall thin, ca. $10 \mu \mathrm{m}$, composed of subhyaline to light brown cells, wall around ostiole ca. 22-50 $\mu \mathrm{m}$ thick, composed of dark brown cells. Conidiophores short, branched up to three times. Condiogenous cells phialidic, cylindrical, (8.5-)9.0$12.3(-15.5) \times(1.5-) 1.7-2.3(-2.7) \mu \mathrm{m}(n=50)$. Conidia $(14-) 17-20(-22) \times(0.9-) 1.1-1.4(-1.7) \mu \mathrm{m}(n=36)$, hyaline, falcate to semicircular, aseptate.

Cultures slow-growing, with uneven lobed margins, colony on CMD reaching $42 \mathrm{~mm}$ diam after 42 days at $16^{\circ} \mathrm{C}$, first whitish, turning medium to dark red brown, with sparse lighter brown aerial mycelium in the centre, reverse zonate, dark brown in the centre, with medium and dark red brown concentric zones towards the margins, entire culture black after 6 months. No conidiomata seen in pure culture.

Habitat: on dead corticated braches of Quercus and Rhamnus alaternus.

Distribution: only known from Mallorca (Spain).

Holotype: Spain, Mallorca, Es Capdellà, Finca Son Marti, on corticated dead branches of Quercus sp., 6 May 2016, A. Pintos AP6516 (WU 39973), ex holotype culture CBS 144700.

Additional specimens examined: Spain, Mallorca, Calvià, Finca Pública Es Galatzó, on corticated dead branches of Quercus coccifera, 14 Dec. 2016, A. Pintos AP141216 (WU 39980); Esporlas, on dead corticated branches of Rhamnus alaternus, A. Pintos, 20 Aug. 2018 AP20818.

Notes: The hysteriform ascomata and 1-septate ascospores of $S$. labiatus are similar to the closely related $S$. pruni, but the latter has distinctly smaller ascospores $(26-35 \times 11-14 \mu \mathrm{m}$ vs. 35-48 $\times 14-19 \mu \mathrm{m}$ in S. labiatus), and it occurs on a different host, Prunus spinosa. In addition, the mature ascospore cells of S. labiatus are more distinctly constricted in the middle and have a ring-like thickening inside the wall.

Stigmatodiscus oculatus Voglmayr \& Pintos, sp. nov. Fig. 5.

MycoBank MB 827488.

Etymology: Referring to its eye-shaped ascomata.

Ascomata hysteriform, scattered to gregarious, corticolous, erumpent through the periderm, commonly arranged in parallel to the branch axis, in face view (160-)280-510(-880) $\mu \mathrm{m}$ long, $(110-) 180-300(-380) \mu \mathrm{m}$ wide $(n=96)$, with sides consisting of usually two, rarely three black lips (peridium) not in mutual contact, with a slit-like to almost circular central opening exposing the blackish elongated to broadly oval disc. Bark tissues not visibly altered, no black line visible in bark or wood. Peridium coriaceous, pseudoparenchymatous, dark brown to black, up to $120 \mu \mathrm{m}$ thick at the apex, 38-55 $\mu \mathrm{m}$ thick at the sides, almost absent to $20 \mu \mathrm{m}$ thick at the base, composed of small angular to rounded cells 3-10 $\mu \mathrm{m}$ diam. Hamathecium composed of hyaline, septate, filiform branched paraphyses 1.7-2.5 $\mu \mathrm{m}$ wide, embedded in tough hymenial gel, simple, not anastomosing, 82-123 $\mu \mathrm{m}$ long, longer than asci, swollen at their apices up to $5.5 \mu \mathrm{m}$ and incrusted with dark brown granules forming an epithecium, neither staining blue in Lugol nor in Melzer's reagent after pre-treatment with $3 \% \mathrm{KOH}$. Asci 72-84(-90) $\times(29-) 35$ $49 \mu \mathrm{m}(n=10)$, bitunicate, clavate to pyriform, almost sessile, with a distinct apical chamber, thick-walled, typically containing 8 irregularly bi- to triseriate ascospores, very stable, fissitunicate dehiscence not observed. Ascospores $(25.5-) 27.5-31(-33) \times(9.5-) 10.5-12.0(-12.5) \mu \mathrm{m}$, $1 / \mathrm{w}=(2.3-) 2.5-2.7(-2.9)(n=63)$, brown, asymmetric, broad ly fusiform, straight, first 1 -septate, developing 2 additional distosepta and becoming 3-septate with age, strongly constricted at the primary septum, weakly at secondary septa, 

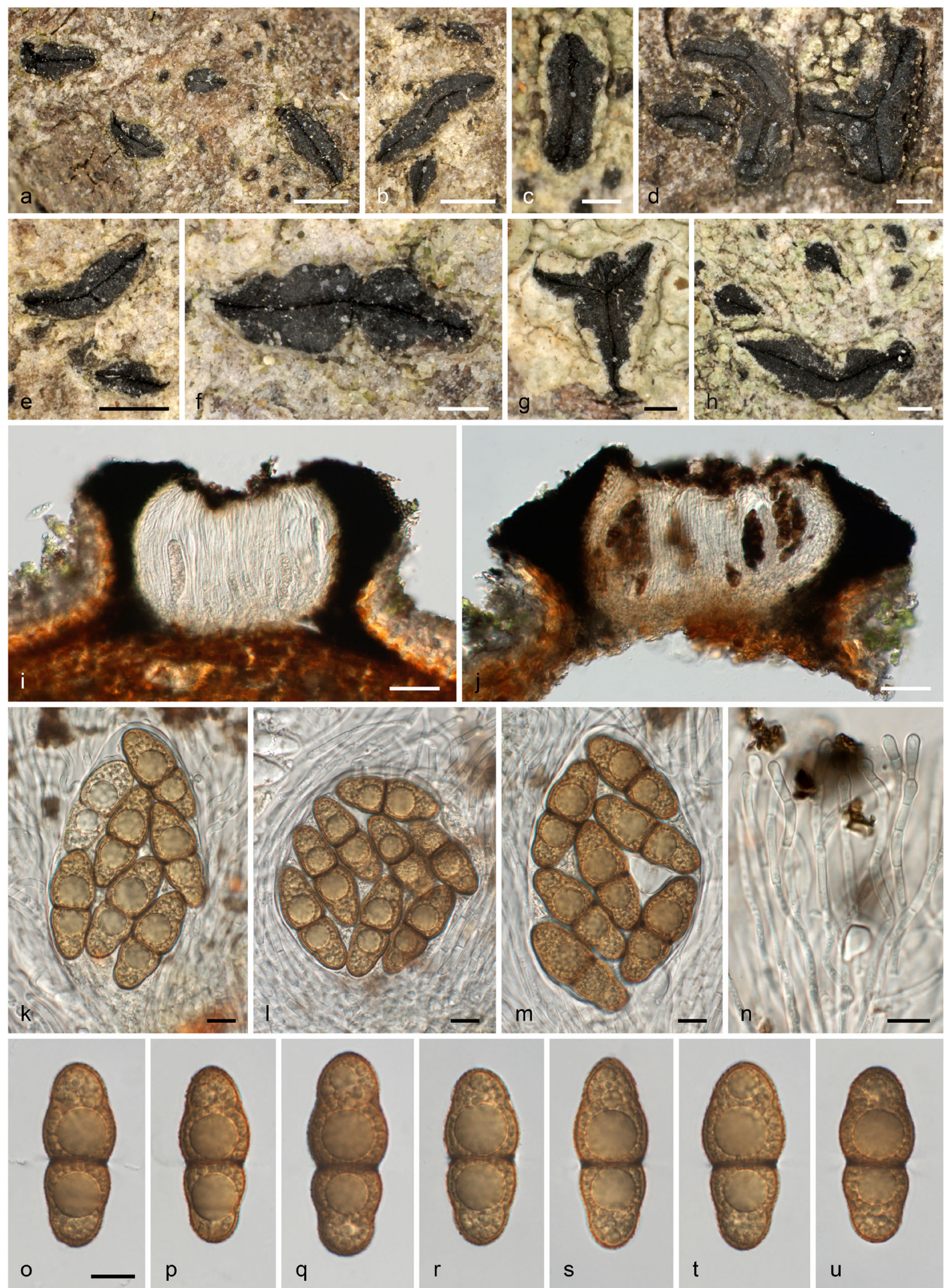

Fig. 3 Stigmatodiscus labiatus, sexual morph. a-h Ascomata erumpent from bark in face view. $\mathbf{i}$, $\mathbf{j}$ Vertical sections of ascomata embedded in bark. $\mathbf{k}-\mathbf{m}$ Asci. $\mathbf{n}$ Apically inflated septate paraphyses, covered by an dark brown amorphous incrustation. o-u Vital ascospores. All in water Sources: a-h, l, o-u WU 39973 (holotype); i-k, m, n WU 39980. Scale bars: a, b, e $500 \mu \mathrm{m} ; \mathbf{c}, \mathbf{d}, \mathbf{f}-\mathbf{h} 200 \mu \mathrm{m} ; \mathbf{i}, \mathbf{j} 50 \mu \mathrm{m} ; \mathbf{k}-\mathbf{u} 10 \mu \mathrm{m}$ 


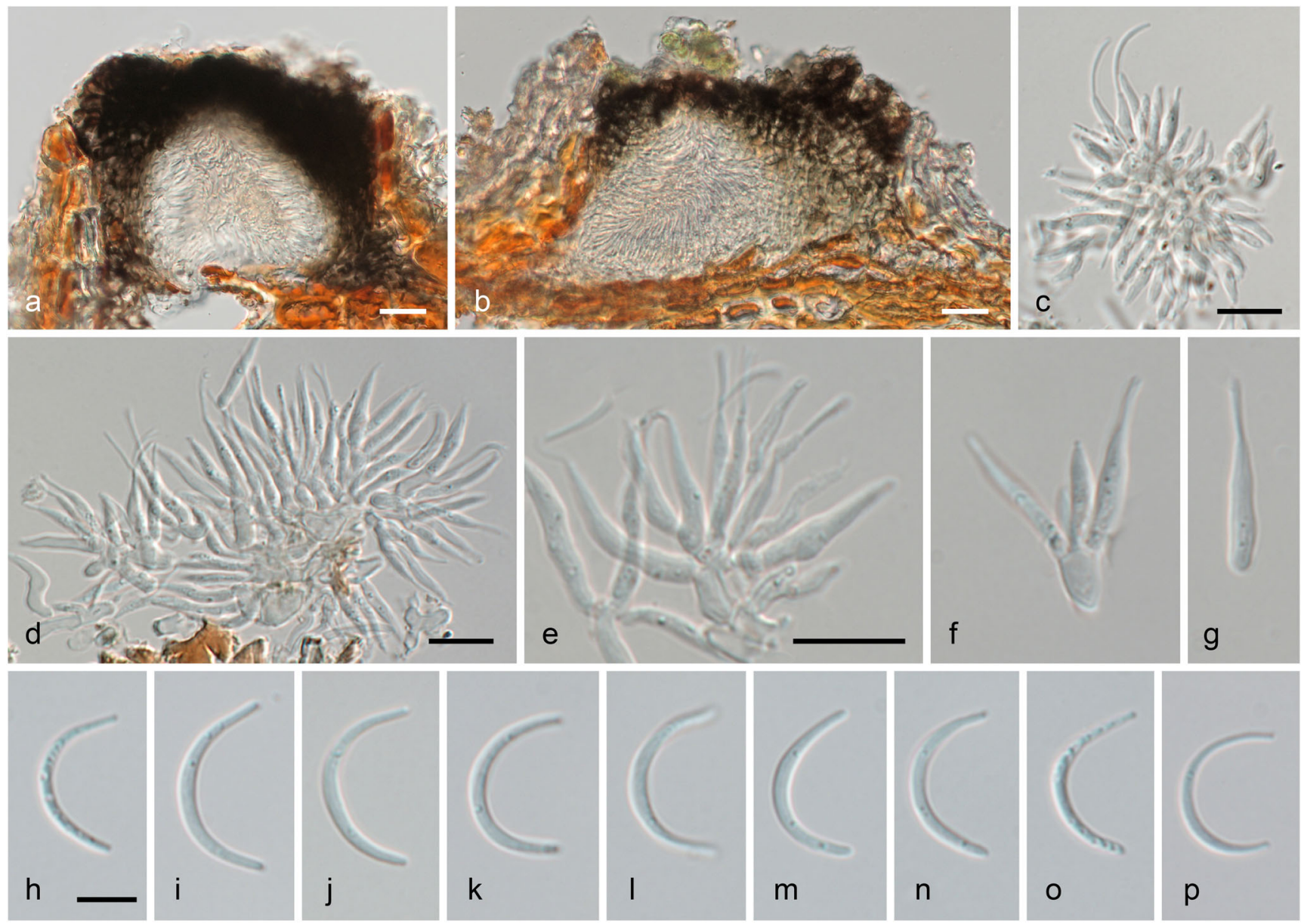

Fig. 4 Stigmatodiscus labiatus, asexual morph. a, b Conidiomata (pycnidia) immersed in periderm in vertical section. c-e Conidiophores with densely aggregated phialides. f, g Phialides. h-p Falcate to

secondary septa with large pores, each hemispore surrounded by a separate gelatinous sheath quickly dissolving in water, upper hemispore slightly broader, with broadly rounded ends; wall finely verruculose, brown, the contents granular, often with a large and several smaller guttules per cell.

Conidiomata on the natural substrate and in pure culture not observed.

Cultures slow-growing, with uneven margins, colony on CMD reaching $58 \mathrm{~mm}$ diam after 42 days at $16{ }^{\circ} \mathrm{C}$, first whitish, soon turning dark olive brown, with abundant woolly surface mycelium, reverse dark brown to black.

Habitat: on dead corticated braches of various Mediterranean trees and shrubs.

Distribution: only known from Mallorca (Spain).

Holotype: Spain, Mallorca, Campos, Sa Ràpita, on corticated dead branches of Olea europaea, 16 Nov. 2016, A. Pintos AP161116 (WU 39974), ex holotype culture CBS 144701.

Additional specimens examined: Spain, Mallorca, Puig de Ros, on dead corticated branches of Populus canadensis, 10 Aug. 2016, A. Pintos AP10816 (WU 39975); Calvià, Playa semicircular conidia. All in water, except a, $\mathbf{c}-\mathbf{g}, \mathbf{p}$ in $3 \% \mathrm{KOH}$. Sources: a, c-g, p WU 39980; b, h-o WU 39973 (holotype). Scale bars: a, b $20 \mu \mathrm{m} ; \mathbf{c}-\mathbf{g} 10 \mu \mathrm{m} ; \mathbf{h}-\mathbf{p} 5 \mu \mathrm{m}$

Portals Vells, on dead corticated branches of Cistus albidus, 23 Oct. 2016, A. Pintos AP231016B (WU 39976); Campos, Sa Ràpita, on dead corticated branches of Pistacia lentiscus, 17 Nov. 2016, AP171116 (WU 39977), Calvià, Portals Vells, on dead corticated branches of Globularia alypum, 31 Dec. 2016, AP311216 and AP311216A (WU 39978).

Notes: Stigmatodiscus oculatus is evidently polyphagous as it has been found on corticated twigs of various shrubs and trees. Within the Stigmatodiscus species with four-celled ascospores, it is well distinct by ascospores smaller than $33 \times$ $12.5 \mu \mathrm{m}$.

Stigmatodiscus pinicola Voglmayr \& Pintos, sp. nov. Figs. 6 and 7.

MycoBank MB 827489.

Etymology: Referring to its growth on Pinus.

Ascomata hysteriform to apothecioid, scattered, corticolous, initially covered by bark, erumpent through the periderm, in face view (205-)255-410(-600) $\mu \mathrm{m}$ long, (145-)180-285(-375) $\mu \mathrm{m}$ wide $(n=30)$, with sides consisting of usually 2-3 black lips (peridium) not in mutual contact, 

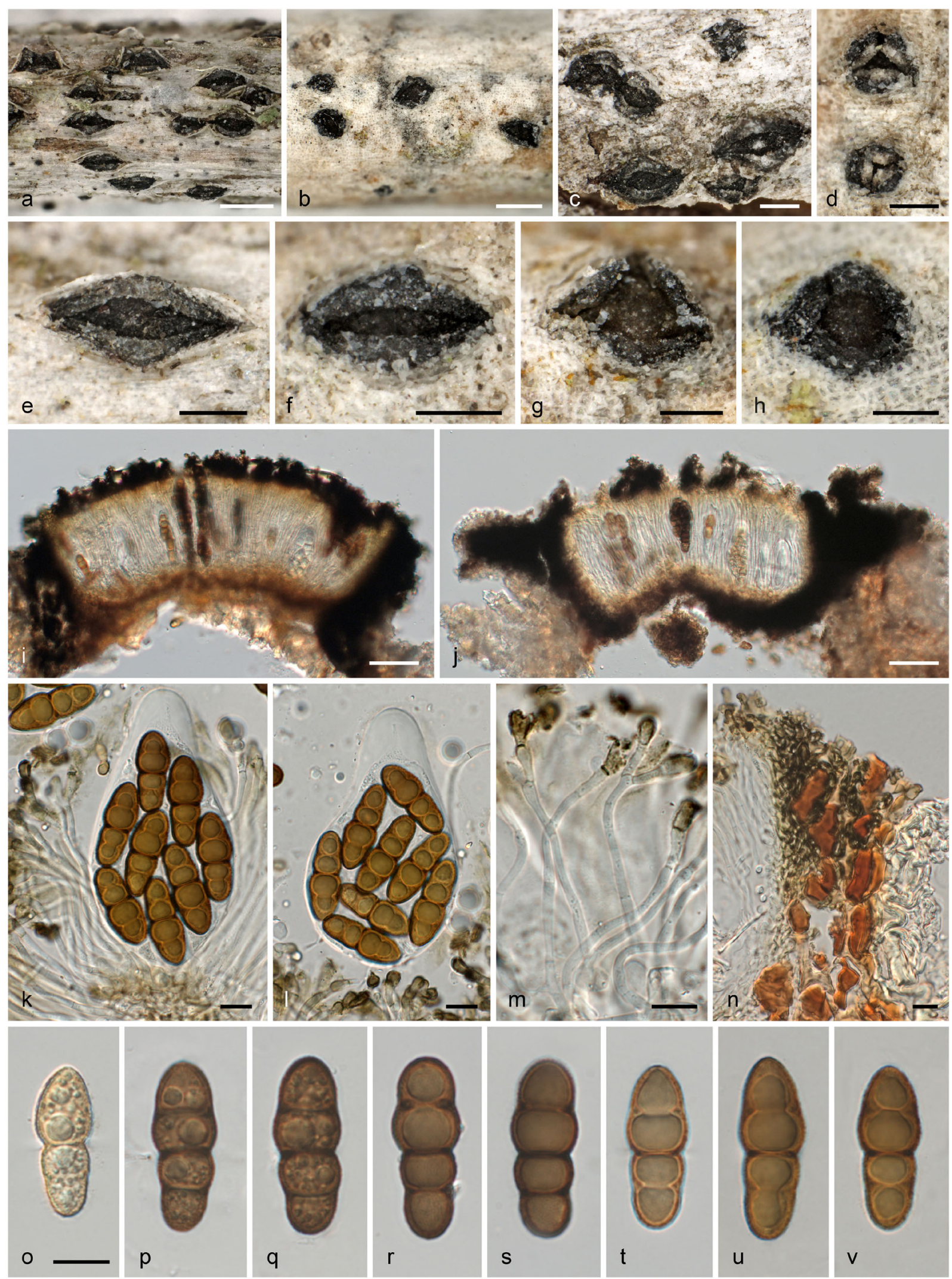

Fig. 5 Stigmatodiscus oculatus, sexual morph. a-h Ascomata erumpent from bark in face view. $\mathbf{i}, \mathbf{j}$ Vertical sections of ascomata embedded in bark. k, I Asci. m Apically inflated septate paraphyses, covered by a dark brown

Ascospores ( $\mathbf{o}$ immature, $\mathbf{p}-\mathbf{v}$ mature; $\mathbf{0}-\mathbf{q}$ vital $\mathbf{r}-\mathbf{v}$ dead). All in water, except $\mathbf{k}-\mathbf{n}, \mathbf{u}, \mathbf{v}$ in $3 \% \mathrm{KOH}$. Sources: a, c, e, $\mathbf{k}-\mathbf{n}, \mathbf{u}, \mathbf{v}$ WU 39977 ; b, d, f-i, r-t WU 39974 (holotype); j, o-q WU 39975. Scale bars: a, b 500 нm; c-h $200 \mu \mathrm{m} ; \mathbf{i}, \mathbf{j} 50 \mu \mathrm{m} ; \mathbf{k}-\mathbf{v} 10 \mu \mathrm{m}$ 

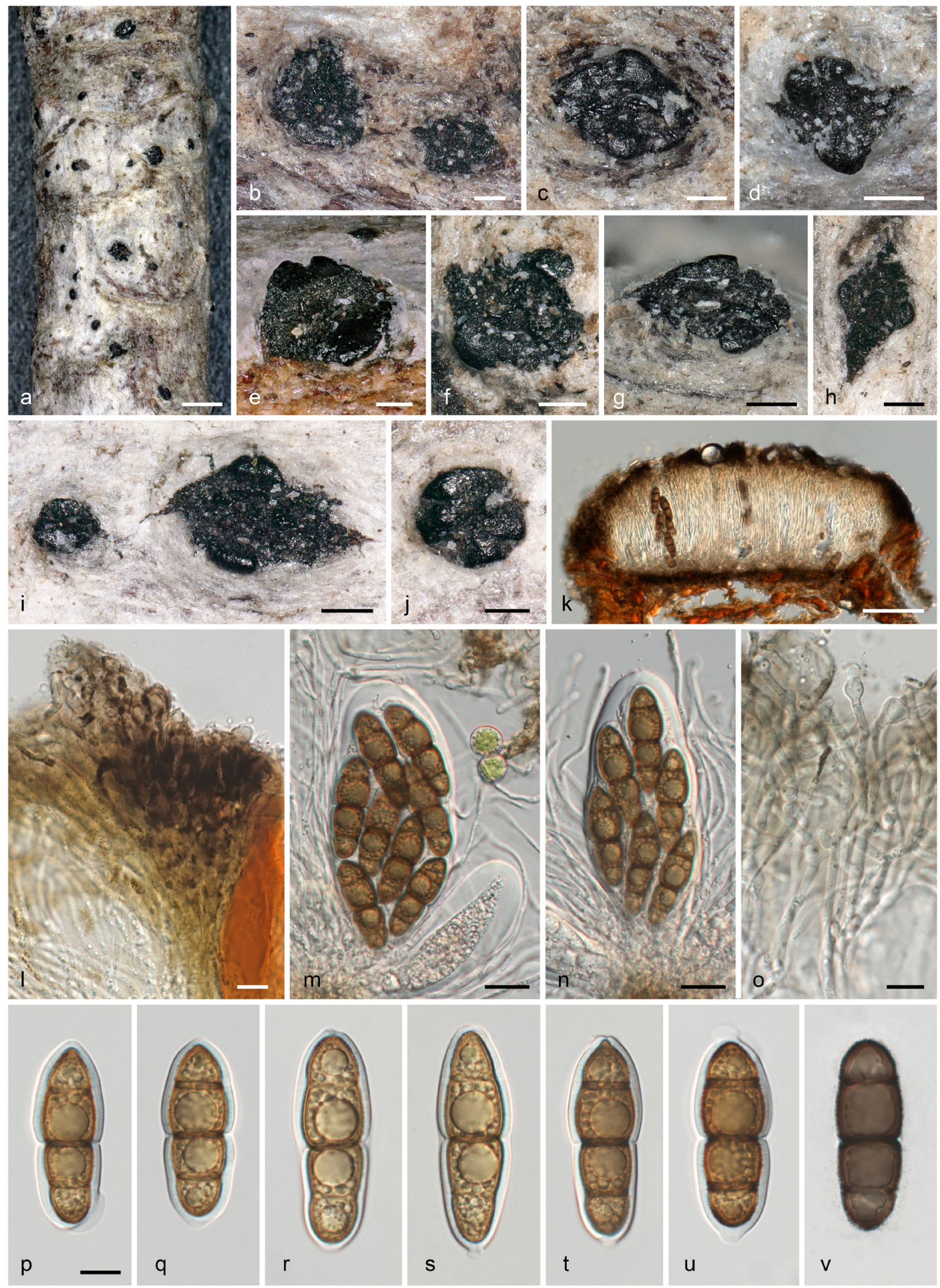

Fig. 6 Stigmatodiscus pinicola, sexual morph (WU 39979, holotype). a-j Ascomata erumpent from bark in face view. $\mathbf{k}$ Vertical section of ascoma. I Ascoma margin in transverse section. m, $\mathbf{n}$ Asci. o Apically inflated septate paraphyses, covered by an dark brown amorphous incrustation. p-v Ascospores (p-u vital, $\mathbf{v}$ dead). All in water, except $\mathbf{l}, \mathbf{o}, \mathbf{v}$ in $3 \% \mathrm{KOH}$. Scale bars: a $500 \mu \mathrm{m} ; \mathbf{b}-\mathbf{k} 100 \mu \mathrm{m} ; \mathbf{m}, \mathbf{n} 20 \mu \mathrm{m}, \mathbf{l}, \mathbf{0}-\mathbf{v} 10 \mu \mathrm{m}$ 

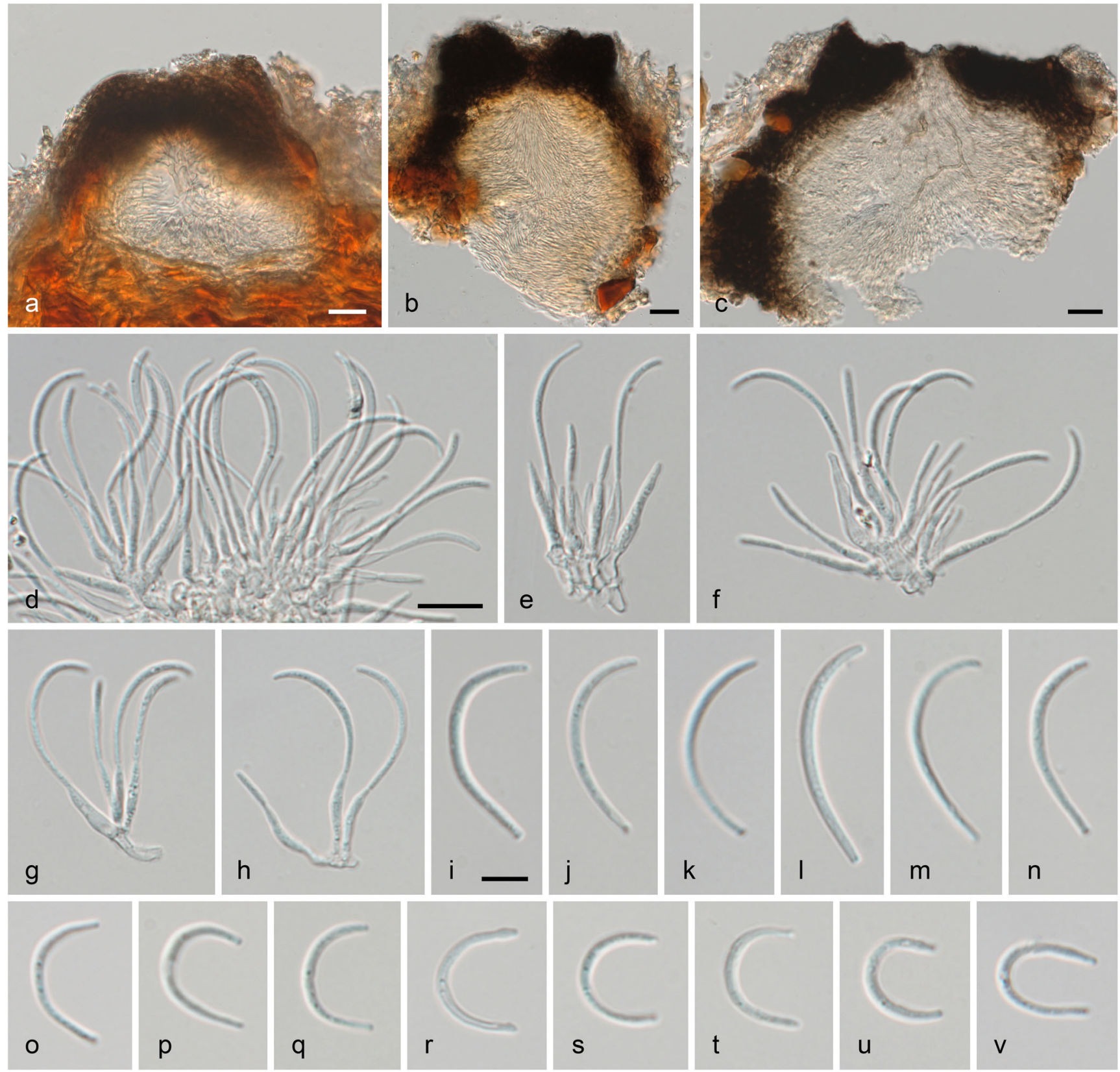

Fig. 7 Stigmatodiscus pinicola, asexual morph (WU 39979, holotype). a-c Conidiomata (pycnidia) immersed in periderm in vertical section; in c through ostiole. $\mathbf{d}-\mathbf{h}$ Conidiophores with densely aggregated phialides. i-

with a slit-like to circular central opening exposing the blackish elongated to circular disc. Bark tissues not visibly altered, no black line visible in bark or wood. Peridium coriaceous, pseudoparenchymatous, dark brown, up to $70 \mu \mathrm{m}$ thick at the apex, 15-25 $\mu \mathrm{m}$ thick at the sides, almost absent to $20(-30)$ $\mu \mathrm{m}$ thick at the base, composed of small angular to rounded brown cells 3-9 $\mu \mathrm{m}$ diam. Hamathecium composed of hyaline, septate, filiform branched paraphyses 1.5-3.5 $\mu \mathrm{m}$ wide, embedded in tough hymenial gel, simple, not anastomosing, ca. 150-220 $\mu \mathrm{m}$ long, longer than asci, swollen at their apices up to $7 \mu \mathrm{m}$ and incrusted with dark brown granules forming

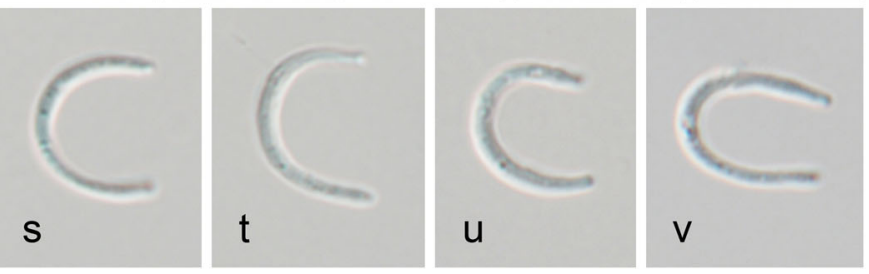

$\mathbf{v}$ Falcate to semicircular conidia. All in water, except b, $\mathbf{c}$ in $3 \% \mathrm{KOH}$. Scale bars: a-c $20 \mu \mathrm{m} ; \mathbf{d}-\mathbf{h} 10 \mu \mathrm{m} ; \mathbf{i}-\mathbf{v} 5 \mu \mathrm{m}$

an epithecium, neither staining blue in Lugol nor in Melzer's reagent after pre-treatment with $3 \% \mathrm{KOH}$. Asci (104-)111$135(-138) \times 47-54(-57) \mu \mathrm{m}(n=10)$, bitunicate, broadly fusiform to ellipsoid, almost sessile, with a distinct apical chamber, thick-walled, typically containing 8 irregularly bi- to triseriate ascospores, very stable, fissitunicate dehiscence not observed. Ascospores (40.5-)43.5-50(-52.5) $\times(13.5-) 14.5-$ $16.8(-18.0) \mu \mathrm{m}, 1 / \mathrm{w}=(2.6-) 2.8-3.2(-3.5)(n=45)$, brown, asymmetric, fusiform, straight, first 1-septate, developing 2 additional distosepta and becoming 3 -septate with age, strongly constricted at the primary septum, weakly at secondary 
septa, secondary septa with large pores, each hemispore surrounded by a separate gelatinous sheath, upper hemispore slightly broader, with subacute to rounded ends, end cells lighter brown at maturity; wall finely verruculose, brown, the contents granular, often with a large and several smaller guttules per cell.

Conidiomata on the natural substrate associated with ascomata, visible as minute black dots $110-200 \mu \mathrm{m}$ in diam, immersed, peridermal, pycnidial, clypeate, unilocular, of circular shape, opening with a central ostiole, $140-230 \mu \mathrm{m}$ diam, 130-210 $\mu \mathrm{m}$ high, marginal wall ca. 14-25 $\mu \mathrm{m}$ thick, of light brown cells, wall around ostiole ca. 30-60 $\mu \mathrm{m}$ thick, composed of brown cells. Ostiole dark brown, ca. 20-25 $\mu \mathrm{m}$ wide. Conidiophores short, branched up to two times. Condiogenous cells phialidic, cylindrical, (9.5-)12.0-17.2($21.2) \times(1.9-) 2.2-2.9(-3.0) \mu \mathrm{m}(n=30)$. Conidia $(18-) 19$ $25(-28) \times 1-1.6 \mu \mathrm{m}(n=30)$, hyaline, falcate to semicircular, aseptate.

Cultures slow-growing, with uneven margins, colony on CMD reaching $49 \mathrm{~mm}$ diam after 42 days at $16{ }^{\circ} \mathrm{C}$, first whitish, then turning black, with sparse grey aerial mycelium, reverse black.

Habitat: on dead corticated braches of Pinus halepensis.

Distribution: only known from Mallorca (Spain).

Holotype: Spain, Mallorca, Es Capdellà, Castell Son Claret, on corticated dead branches of Pinus halepensis, 21 Sep. 2016, A. Pintos AP21916B (WU 39979), ex holotype culture CBS 144702.

Notes: Stigmatodiscus pinicola is well characterised by the small apothecioid-hysteriform ascomata with usually circular outline and indistinct lips and by its host, Pinus halepensis. Stigmatodiscus enigmaticus and $S$. tamaricis also have fourcelled ascospores of similar size but have different hosts; in addition, $S$. enigmaticus differs by larger ascomata (0.4-1.5 vs. $0.2-0.4(-0.6) \mathrm{mm}$ ) which are surrounded by bark flaps, and $S$. tamaricis by ascospores long remaining (sub)hyaline and by paraphyses with emerald to deep blue amorphous incrustation (Voglmayr et al. 2016).

Stigmatodiscus tamaricis (Voglmayr, Gardiennet \& Jaklitsch) Voglmayr \& Jaklitsch, comb. nov.

MycoBank MB 827490.

Basionym: Asterodiscus tamaricis Voglmayr, Gardiennet \& Jaklitsch, Fungal Diversity 80: 276 (2016).

Specimen examined: Spain, Mallorca, Calvià, Magalluf, on corticated dead branches of Tamarix sp., 9 Sep. 2016, A. Pintos AP9916A.

Notes: With the addition of Stigmatodiscus oculatus, Asterodiscus tamaricis becomes phylogenetically embedded within Stigmatodiscus and is therefore transferred to the latter. Stigmatodiscus tamaricis is widely distributed on Tamarix spp. in Central and Southern Europe, and the specimen cited above is the second record of the species for Mallorca; the first
Mallorcan record was recently published in Siquier et al. (2018).

\section{Key to the species of Stigmatodiscus}

1. Ascospores at maturity with a primary septum, only very rarely developing two additional distosepta, brown; ascomata distinctly hysteriform.

...2

Ascospores at maturity with a primary septum and two additional distosepta, hyaline or brown; ascomata apothecioid or hysteriform.

...3

2. Ascospores (26.5-)29-32.5(-34.5) × (10.8-)11.5-12.7(13.8) $\mu \mathrm{m}$; on Prunus spinosa ................................ p. pruni

Ascospores (34.5-)38-43(-47.5) ×(13.8-) 15.517.5(-19.3) $\mu \mathrm{m}$; on Mediterranean Quercus spp...

S. labiatus

3. Mature ascospores in vital asci hyaline to light brown, becoming dark brown after ejection, (33.5-)40$45(-49) \times(12.8-) 14.3-16.5(-17.7) \mu \mathrm{m}$; ascomata apothecioid, circular; paraphyses tips covered by an olivaceous, emerald to deep blue amorphous incrustation; on Tamarix spp. S. tamaricis

Mature ascospores brown; paraphyses tips covered by a dark brown amorphous incrustation; on other hosts......

4. Ascospores $(25.5-) 27.5-31(-33) \times(9.5-) 10.5-12.0(-$ 12.5) $\mu \mathrm{m}$; ascomata hysteriform; polyphagous.. S. oculatus

Ascospores larger than $40 \times 13 \mu \mathrm{m}$, ascomata mostly circular, apothecioid

5. Ascomata $0.4-1.5 \mathrm{~mm}$ diam, surrounded by irregular bark flaps; ascospores (46-)54-64 (-73) $\times(16.5-) 20.0$ 24.3(-32.5) $\mu \mathrm{m}$; on Acer spp., Carpinus orientalis................................................ S. enigmaticus

Ascomata $0.2-0.4(-0.6) \mathrm{mm}$ diam, not surrounded by bark flaps; ascospores (40.5-)43.5-50($52.5) \times(13.5-) 14.5-16.8(-18.0)$; on Pinus halepensis. S. pinicola

\section{Discussion}

Voglmayr et al. (2016) established the two genera Asterodiscus and Stigmatodiscus within the new family and order Stigmatodiscaceae and Stigmatodiscales, respectively, primarily based on differences in ascomatal shape and hyaline vs. brown ascospores. The morphological boundaries and phylogenetic differences between the two genera were considered distinct enough for establishing two genera. This concept was already challenged by Voglmayr et al. (2017), who described $S$. pruni, another new species with brown but two- 
celled ascospores, which differed substantially from the generic type, S. enigmaticus, by distinctly hysteriform ascomata.

The results of the current phylogenies necessitate a reevaluation of the genus Asterodiscus, because it forms a highly supported clade with Stigmatodiscus oculatus. Whereas the ascospore shape and septation of $S$. oculatus are similar to A. tamaricis, the brown ascospores are indicative of Stigmatodiscus. Therefore, if the genus Asterodiscus were maintained, this would necessitate an emendation of the genus. However, considering the morphology of the new species described since the study of Voglmayr et al. (2016), the morphological differences between Asterodiscus and Stigmatodiscus seem insufficient to maintain them as distinct genera, which are therefore here synonymised.

None of the newly described species produced asexual morphs in pure culture; however, in S. labiatus and $S$. pinicola, an asexual morph was found tightly associated with the sexual morphs on the natural substrate. As conidia did not germinate on MEA or CMD, the connection with the sexual morphs could not be experimentally proven. However, we are confident that the associated asexual morphs belong to the respective species, as the morphology of their conidiomata as well as their conidial ontogeny, size, and shape fully match the asexual morph of $S$. enigmaticus, which was documented from natural substrate as well as pure cultures originating from ascospores (Voglmayr et al. 2016), proving the connection.

It is astonishing that within a small area, three new species of Stigmatodiscus could be found. It remains so far unclear whether the new species are endemic to Mallorca, or whether they co-occur with their widely distributed hosts in other regions the Mediterranean. This once again demonstrates that in the Mediterranean, the species diversity of corticolous ascomycetes is very incompletely studied, and that many species still await description (e.g. Voglmayr and Jaklitsch 2011; Jaklitsch and Voglmayr 2011, 2014; Voglmayr et al. 2016; Jaklitsch et al. 2014, 2015, 2018a, b; Galán et al. 2015; Checa et al. 2015). Considering that the Mediterranean is amongst the main biodiversity hotspots of the world (Myers et al. 2000), additional species of Stigmatodiscus are likely to be detected in this species-rich area.

Funding Information Open access funding provided by University of Vienna.

Open Access This article is distributed under the terms of the Creative Commons Attribution 4.0 International License (http:// creativecommons.org/licenses/by/4.0/), which permits unrestricted use, distribution, and reproduction in any medium, provided you give appropriate credit to the original author(s) and the source, provide a link to the Creative Commons license, and indicate if changes were made.

\section{References}

Carbone I, Kohn LM (1999) A method for designing primer sets for speciation studies in filamentous ascomycetes. Mycologia 91:553-556

Checa J, Jaklitsch WM, Blanco MN, Moreno G, Tello S et al (2015) Two new species of Thyronectria from Mediteranean Europe. Additions to genus. Mycologia 107:1314-1322

Galán R, Checa J, Blanco MN, Platas G, Tena R et al (2015) Taxonomic position of the genus Bicornispora and the appearance of a new species Bicornispora seditiosa. Mycologia 107:793-807

Hall TA (1999) BioEdit: a user-friendly biological sequence alignment editor and analysis, program for Windows 95/98/NT. Nucleic Acids Symp Ser 41:95-98

de Hoog GS, Gerrits van den Ende AHG (1998) Molecular diagnostics of clinical strains of filamentous basidiomycetes. Mycoses 41:183-189

Jaklitsch WM, Voglmayr H (2011) Nectria eustromatica sp. nov, an exceptional species with a hypocreaceous stroma. Mycologia 103: 209-218

Jaklitsch WM, Voglmayr H (2014) Persistent hamathecial threads in the Nectriaceae, Hypocreales: Thyronectria revisited and re-instated. Persoonia 33:182-211

Jaklitsch WM, Komon M, Kubicek CP, Druzhinina IS (2005) Hypocrea voglmayrii sp. nov. from the Austrian Alps represents a new phylogenetic clade in Hypocrea / Trichoderma. Mycologia 97:1365-1378

Jaklitsch WM, Fournier J, Rogers JD, Voglmayr H (2014) Phylogenetic and taxonomic revision of Lopadostoma. Persoonia 32:52-82

Jaklitsch WM, Fournier J, Dai DQ, Hyde KD, Voglmayr H (2015) Valsaria and the Valsariales. Fungal Divers 73:159-202

Jaklitsch WM, Checa J, Blanco MN, Olariaga I, Tello S et al (2018a) A preliminary account of the Cucurbitariaceae. Stud Mycol 90:71-118

Jaklitsch WM, Fournier J, Voglmayr H (2018b) Two unusual new species of Pleosporales: Anteaglonium rubescens and Atrocalyx asturiensis. Sydowia 70:129-140

Kauff F, Lutzoni F (2002) Phylogeny of Gyalectales and Ostropales (Ascomycota, Fungi): among and within order relationships based on nuclear ribosomal RNA small and large subunits. Mol Phylogenet Evol 25:138-156

Landvik S, Egger K, Schumacher T (1997) Towards a subordinal classification of the Pezizales (Ascomycota): phylogenetic analyses of SSU rDNA sequences. Nordic J Bot 17:403-418

Liu YL, Whelen S, Hall BD (1999) Phylogenetic relationships among ascomycetes: evidence from an RNA polymerase II subunit. Mol Biol Evol 16:1799-1808

Mapook A, Hyde KD, Hongsanan S, Phukhamsakda C, Li JF et al (2016) Palawaniaceae fam. nov., a new family (Dothideomycetes, Ascomycota). Mycosphere 7:1732-1745

Myers N, Mittermeier RA, Mittermeier CG, da Fonseca GA, Kent J (2000) Biodiversity hotspots for conservation priorities. Nature 403:853-858

Nelsen MP, Lücking R, Grube M, Mbatchou JS, Muggia L et al (2009) Unravelling the phylogenetic relationships of lichenised fungi in Dothideomyceta. Stud Mycol 64:135-144

Nelsen MP, Lücking R, Mbatchou JS, Andrew CJ, Spielmann AA et al (2011) New insights into relationships of lichen-forming Dothideomycetes. Fungal Divers 51:155-162

O’Donnell K, Cigelnik E (1997) Two divergent intragenomic rDNA ITS2 types within a monophyletic lineage of the fungus Fusarium are nonorthologous. Mol Phylogenet Evol 7:103-116

Rehner SA, Buckley E (2005) A Beauveria phylogeny inferred from nuclear ITS and EF1- $\alpha$ sequences: evidence for cryptic diversification and links to Cordyceps teleomorphs. Mycologia 97:84-98

Silvestro D, Michalak I (2012) raxmlGUI: a graphical front-end for RAxML. Org Divers Evol 12:335-337 
Siquier JL, Salom JC, Vega M, Pintos A, Llistosella J (2018) Contribució al coneixement micològic de les Illes Balears (Espanya). XXIV. Rev Catalana Micol 39:3-22

Stamatakis E (2006) RAxML-VI-HPC: maximum likelihood-based phylogenetic analyses with thousands of taxa and mixed models. Bioinformatics 22:2688-2690

Suetrong S, Schoch CL, Spatafora JW, Kohlmeyer J, VolkmannKohlmeyer B et al (2009) Molecular systematics of the marine Dothideomycetes. Stud Mycol 64:155-173

Swofford DL (2002) PAUP* 4.0b10: phylogenetic analysis using parsimony (*and other methods). Sinauer Associates, Sunderland

Vilgalys R, Hester M (1990) Rapid genetic identification and mapping of enzymatically amplified ribosomal DNA from several Cryptococcus species. J Bacteriol 172:4238-4246

Voglmayr H, Jaklitsch WM (2008) Prosthecium species with Stegonsporium anamorphs on Acer. Mycol Res 112:885-905
Voglmayr H, Jaklitsch WM (2011) Molecular data reveal high host specificity in the phylogenetically isolated genus Massaria (Ascomycota, Massariaceae). Fungal Divers 46:133-170

Voglmayr H, Rossman AY, Castlebury LA, Jaklitsch W (2012) Multigene phylogeny and taxonomy of the genus Melanconiella (Diaporthales). Fungal Divers 57:1-44

Voglmayr H, Gardiennet A, Jaklitsch WM (2016) Asterodiscus and Stigmatodiscus, two new apothecial dothideomycete genera and the new order Stigmatodiscales. Fungal Divers 80:271-284

Voglmayr H, Fournier J, Jaklitsch WM (2017) Stigmatodiscus pruni, a new dothideomycete with hysteriform ascomata. Sydowia 69:29-35

Werle E, Schneider C, Renner M, Völker M, Fiehn W (1994) Convenient single-step, one tube purification of PCR products for direct sequencing. Nucleic Acids Res 22:4354-4355

White TJ, Bruns T, Lee S, Taylor J (1990) Amplified and direct sequencing of fungal ribosomal RNA genes for phylogenies. In: Innis MA, Gelfand DH, Sninsky JJ, White TJ (eds) PCR protocols: a guide to methods and applications. Academic Press, San Diego, pp 315-322 